\title{
A Study on the Micro Enterprises Promoted by Kudumbashree and their Marketing Strategies in Malappuram District
}

\author{
M.K. Irshad and B.K. Muhammed Juman
}

\begin{abstract}
The role of micro enterprises in rural development and women empowerment is widely recognized the world over, particularly in developing nations like India. Micro enterprises play a vital role in poverty alleviation and socio-economic development of the poor. Micro enterprises help to bring about equitable and balanced economic development with relatively low amount of capital investment. The Government of Kerala State has introduced a novel scheme of poverty alleviation based on micro-credit and self help grouping. Paraphrased as Kudumbashree ('Prosperity of the Family'), the scheme aims at improving the living levels of the poor women in rural and urban areas. The project aims at removing poverty among rural women households through setting up of micro-credit and productive enterprises. The activities such as micro-credit and micro-enterprises under the scheme were undertaken by the locally formed Community Development Societies consisting of poor women.
\end{abstract}

The State Poverty Eradication Mission-Kudumbashreelaunched by the Government of Kerala in India is a massive poverty eradication programme in contemporary history especially in Malappuram. It has been proven without doubt that women empowerment is the best strategy for poverty eradication. Women, who were regarded as voiceless and powerless started identifying their inner strength, opportunities for growth, and their role in reshaping their own destiny. The process of empowerment becomes the beacon light to their children, their families and the society at large. It opens a new vista the in development history. This paper looks in to the role of micro enterprises functioning under Kudumbashree in the economic development of Malappuram district and their marketing strategies.

Keywords--- Kudmbashree, Micro Enterprise, Empowerment, Economic Development

M.K. Irshad, Research Scholar, Bharathiar University, Coimbatore, Manar Manzil, Thottilangadi (P.O.), Irivetty, Areacode Via, Malappuram673639.E-mail:irshadmkmaxmax@gmail.com

B.K. Muhammed Juman, Research Scholar, Bharathiar University, Coimbatore, Darul Birru(H), Puthalam, Areacode (P.O.), Malappuram673639. E-mail:juman.bk@gmail.com

DOI: 10.9756/BIJIEMS.8086

\section{INTRODUCTION}

$\mathrm{K}$ UDMBASHREE is a poverty eradication project officially launched by the Government of Kerala with the active support of the Centre and NABARD for wiping out absolute poverty from the State within 10 years. The project was inaugurated by the Prime Minister, Shri Atal Bihari Vajpayee, on May 17, 1998 at Malappuram. The project is implemented by the State Poverty Eradication Mission of the State government through local self-governing bodies. It aims at eradicating poverty in ten years through concerted community action under the leadership of local self government bodies. This mission is the transformation of earlier Urban Poverty Alleviation Programmes (UPAP) like Urban Basic Services (UBS) and Urban Basic Services for the Poor (UBSP) which had been successfully implemented for improving the livelihood of the poor in urban areas with community participation. The success of UBS/UBSP projects prompted the State Government to extend this project to all urban local bodies in the State. The implementation of Government-sponsored programmes for improving health and sanitation in Malappuram District was channeled through neighbourhood groups. For effective implementation of Kudumbasree a community-based organisation is in action. The Neighbourhood Group (NG) consisting of 20-40 women are selected from poor families. Meetings are convened on a weekly basis in the house of NG members. To co-ordinate activities of each NG, five volunteers from among the members of the group are selected. Besides empowering women through community-based organisation, Kudumbasree encourages and guides them to start small enterprises. Products manufactured by such enterprises are sold through rural marketing network.

Kudumbashree views Micro Enterprise Development as an opportunity for providing gainful employment to the people below poverty line and thereby improving their income and living standard. Micro enterprise development is an emerging process which will start with low capital low risk and low profit at the initial stage which will gain momentum and later switch on to low to medium capital and then to low to medium risk. This Paper aims at examining the socio-economic impact of the Kudumbashree projects and the role of micro enterprises functioning under Kudmbashree along with their marketing strategies and enhance to provide suggestion regarding their functioning for the economic development of Malappuram district, Kerala. 


\section{ENTREPRENEURSHIP DEVELOPMENT}

Entrepreneurship is the vibrant assertion of the facts that an individual can be developed, outlook can be changed and their ideas can be converted into action through an organized and systematic program for entrepreneurs.An entrepreneurship need not be only on individual level but also functional level need to be developed. Entrepreneurship simply means creation of business or starting of business. It is the process of changing ideas into commercial opportunities and creating values.

\section{Operational Definitions}

\section{Area Development Society (ADS)}

Area Development Society (ADS) is the federation of 8-10 NHG's formed at ward level, consists of representatives of the poor elected from various federating NHGs. The Area Development Society functions through three distinct bodies' viz., General Body, Governing Body and Monitoring and Advisory Committee.

\section{Community Development Society (CDS)}

Community Development Society (CDS) is a registered body under the Charitable Societies Act is formed by federating various ADS's at Panchayath level. The CDS has three distinct bodies viz, General Body, Governing Body and Monitoring \& Advisory Committee

\section{Micro Enterprises}

Micro enterprise is any income generating activity owned, operated and managed by a group, consisting of at least five and not more than fifteen women members of the Kudumbashree NHG s with an investment ranging from Rs 5000 to Rs 5 lakh and should have a potential to generate atleast Rs 1500 per member per month by way of wages or profit or both together, with an expectation of turnover ranging from Rs 1 lakh to Rs 5 lakh per year”.

\section{Neighbourhood Group (NHG)}

It consists of women from $20-40$ families and acts at grassroots level .NHG are the building block of the organisation. In each Neighbourhood Group from among its members, five Volunteers are elected for undertaking various functional activities. They are Secretary, President, Community Health Volunteer, Income generation activities volunteer and Infrastructure Volunteer.

\section{Women Entrepreneur}

Women entrepreneurs are those who organize or operate and control an enterprise including small and cottage industries with not less than $80 \%$ of the total workers being woman and whose holding in the enterprise is at least $51 \%$.

\section{REVIEW OF LiterAtURE}

Kannan (et al) (2004) made an attempt to analyze the significance of informal women entrepreneurs in generating income for their families'. The major findings of the study arewomen entrepreneurs depend upon the family for involvement in entrepreneurship. The major reason for involvement in informal trade is due to poverty in their families. In rural
India, women turn to self employment and entrepreneurship as a means of earning for livelihood. The study was conducted in five villages around Tuticorn town.

Mohammed Seik (et al) (2004) suggested that in the rural context women's control over ownership of land can play an important role not only in economic betterment but also in terms of social and political empowerment as land is the symbol of political power and social status. Micro credit programmes have to be visualized in the context of new global economic order in liberalization, globalization and privatization policies which have led to job losses in the formal sector decline in social sector spending and growing unemployment. In this scenario the last option left for poor women is self-employment, which micro credit aims to promote. He concluded that since the efficiency of micro credit programmes is not independent of other developmental interventions, it could at best be one of the components of wider developmental agenda.

TK Jose, Executive Director of Kudumbashree (2006) commented that Kudumbashree views Micro Enterprise Development as an opportunity for providing gainful employment to the people below poverty line and thereby improving their income and living standard. In setting up of Micro enterprises for the poor and enabling to take up livelihood activities Kudumbashree has developed its own methodology. So far 27477 women from urban area and 2.07 lakh women from rural areas were given the sustainable selfemployment opportunities with reasonable income.

\section{OBJective OF THE STUdy}

1. To study the functioning of Kudumbashree unit in Malappuram

2. To analyse the role played by the Micro enterprises promoted by Kudumbashree in the Economic empowerment of Women.

3. To analyse financial performance of Micro enterprises under Kudumbashree

4. To Understand the investment pattern of Micro enterprises

5. To trace out the mode of advertising adopted by each micro enterprises

6. To trace out different marketing strategies adopted by various Kudumbashree Micro enterprises

7. To trace out the hurdles faced by Kudumbashree Micro enterprises in marketing

\section{SCOPE AND SigNIFICANCE}

Scope

To understand the impact of Kudumbashree, one simply has to look at its scope. The 41-lakh members in the movement translate into nearly $50 \%$ of the households in the state. In other words, half the state's population makes a living out of this programme. Kudumbashree's success gains even more shine because of one constant problem in Kerala. The men usually spend a big part of their income on vices such as liquor, cigarettes, drugs and gambling. 
Kudumbashree today runs about 35,000 microenterprises in fields as diverse as food processing and handicraft and cosmetics. Remember that these units are managed by women from poor families with no formal training. Scope of the present study is confined to the role of Kudumbashree Micro enterprises in poverty alleviation, Women empowerment and overall economic development of Malappuram

\section{Significance}

1. It help to understand the role of Kudumbashree in Micro enterprises in economic development of Malappuram

2. It helps to know the role played by Micro enterprises in Women empowerment and poverty alleviation.

3. It helps to explain the financial performance of Micro enterprises.

\section{RESEARCH METHODOLOGY}

\section{Sources of Data}

Both primary and secondary data will be used for the purpose of study. Primary data is collected from Kudumbasree Micro enterprises and member beneficiaries.

Secondary data required for the study is obtained from journals, magazines, books and other periodicals and report of Government of India, and Governmemnt of Kerala.

\section{The Modes Operandi}

The formation of the grass root level Community Based Organisation (CBO) is the fulcrum of the Kudumbashree mission. The grass root level poor women are organized through Neighbourhood Groups (NHGs) consisting of 20-40 women with 5 functional volunteers, viz.,

- Community Health Volunteer

- Income Generation Volunteer

- Infrastructure Volunteer

- Secretary, and

- President

The Neighbourhood Groups (NHGs) are coordinated at ward level through Area Development Society (ADS) by federating 8 to 10 NHGs. To coordinate the activities at the Panchayat level there is the apex body called Community Development Society (CDS), which is heading the Area Development Societies.(ADSs).

The CBOs are the lifeblood of Kudumbashree. The NHG members used to meet once in a week in one of the member's house. The members, who meet together, discuss their problems and make joint effort to find solutions to their grievances with the support of the functional volunteers. This would bring up interpersonal feelings among the members and would generate supportive attitude to build confidence among them. Apart from this, they practice small savings through thrift which should be used to create productive assets. The formulation of micro, mini and sub-plans help facilitate the poor women households to participate in planning process as a major stake holder.

The activities of the Malappuram CDS include Training and Orientation Programme for Women, Imparting Education for Children, Regular Meetings to share experiences and holding cultural programmes, Community Health Care, Environmental Sanitation and Informal Banking through Thrift and Credit Societies and Self -Help Groupings. The present structure of Kudumbashree

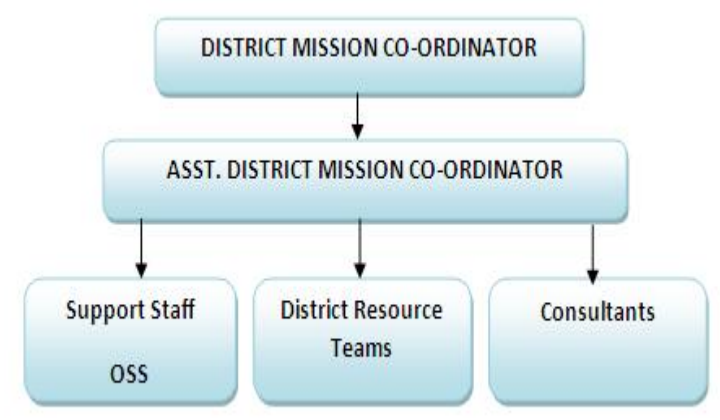

\section{Motto of Kudumbashree}

Social Empowerment, Women's Empowerment, Economic Empowerment

\section{Building a Future}

The amazing success of the participatory system of poverty alleviation in Alappuzha Municipality prompted the Government of Kerala in 1994 to extend the scheme to the entire district of Malappuram, one of the most backward districts in India. The district of Malappuram has the highest fertility and infant mortality rates in Kerala. The Government of Kerala , with the assistance of the UNICEF , chose the district of Malappuram to experiment with poverty alleviation programme called Community Based Nutrition Project and Poverty Alleviation Programme (CBNP \&PAP) aiming at helping to reach out the unreached through community action. The strategy formed the Convergent Community Action and Self Help to enhance the capacity of the family to help meet their basic needs such as drinking water, primary health care, basic education, safe environment and food security. The non economic risk indicators adopted for Malappuram model are:

- Families with substandard houses and huts

- Family with no sanitary latrines

- Families having no safe drinking water supply within atleast 300 mteres

- Families having more than 6 members

- Families with only one earning member

- Families belonging to SC/ST

- Families having illiterate members

- Families having only 2 meals or less a day

- Families having alcoholics, widows and divorcees

Initially, the Kudumbashree movement restricted itself to a few areas in farming and agri-business such as rice and vegetable cultivation and making curry powder, pickles, rice powder and so on. Members have since ventured into fields such as construction, driving, cafes, brand development long seen as the preserve of men in Kerala. 
Jams is a successful micro-enterprise in Manjeri municipality of Malappuram. It is well known today for its breakfast kit of pathiri powder, puttu powder, wheat powder and rava powder, in half kilogram packs. The two kilogram kit priced at Rs.65 makes for a healthy breakfast for a family for a week. The kits are attractively packed in cloth bags. In addition to these Jams also makes one kilogram idli mix packets priced at Rs.54 and one kilogram dosa mix packets priced at Rs.56. The group also purchases mustard, cumin and fenugreek seeds in bulk at wholesale prices and after washing, drying and packing them delivers them in shops. All these ventures have been profitable and the group has been able to purchase a goods carrier to take its produce around. Jams member Ambika says that they are always on the lookout for new opportunities depending on market needs. During bakrid this year they made special payampori which sold well.

The eight women in Jams believe in the adage 'unity is strength'. They started working together three years ago producing Nutrimix for anganwadis. The unit was set up with an investment of Rs.2.5 lakhs of which Rs.1.5 lakhs was mobilised as subsidy and member contributions of Rs.12,500 each. They were able to supply Nutrimix to 103 anganwadis. Since the machinery was not utilised to the full they decided to diversify and make the breakfast powder kits. The group constantly strives to be different. Each month they make sales of upto Rs.1.5 lakhs. The members of the unit Ambika, Jayanti, Ramlat, Mini, Saraswati, Sheeja, Muneera and Cecily, the group leader work on all days of the week, often even on Sundays. Their commitment and focus are contributors to their success. Areca palm leaf is another important product now a days available in market. It has been started at Edavanna, Malappuram with a variety of products related with areca palm leaf.

\section{LIMITATIONS OF THE STUDY}

1. The research area is restricted to Malappuram District.

2. The sample size is limited to 30 respondents.

3. The study is restricted to the women micro enterprises formed and organized by the District Kudumbashree Mission.

4. The respondents are either the secretary or the president only of the microenterprise who acts as leader in respective groups.

5. The district coordination team of Kudumbashree, Panchayath level community organizers and office bearers of CDS who really organize and monitor the Kudumbashree micro enterprise activities not come under respondent category.

\section{FINDINGS}

- It was found that majority of the respondents around $83.33 \%$ are exposed to training at the initial stages of the establishments of the units.

- In the initial stages it was seen that $87 \%$ got training in manufacturing, $90 \%$ in marketing, and 50\% in personnel selling, on general orientation.

- Only 90\% got training on marketing and 7\% never attended any training on marketing.
- It is seen that $50 \%$ of the respondents depends on personnel selling, $40 \%$ on sales promotion, while only $10 \%$ depends on advertisement to promote their product.

- $\quad$ From the study it was concluded that only $40 \%$ of the respondents advertise their product. 75\% have designed their own logo and only 25\% assigned outside agency for advertising their product.

- It was observed from the study that $43.33 \%$ of the total respondents have not spent any amount for branding. $16.67 \%$ spent a sum between Rs 3000 to Rs.10000 for branding and advertisement whereas $10 \%$ spent a sum above Rs.10000. 30\% of the total population did not respond to the question.

- From the study it was found that $90 \%$ of the respondents are getting assistance from Kudumbashree in the marketing activities.

- It was clearly observed that $73.33 \%$ of the respondents expect financial assistance from Kudumbashree.

- $60 \%$ of the respondents are getting financial assistance from Kudumbashree

- It is seen the $46.67 \%$ of the respondents have not developed separate slogan for their micro enterprises.

- It is inferred that $70 \%$ of the respondents believe that advertisement has made a tremendous impact on total sales whereas 23.33\% feels advertisements has no impact on sales volume and $6.67 \%$ did not respond.

\section{SUGGESTIONS}

- Motivation and Leadership classes must be conducted by the organisation which will definitely help the entrepreneurs to deal with people, lessen conflicts among the groups, boost morale, increase self confidence and gain self respect.

- Kudumbashree must ensure that Special camps, orientation classes, workshops must be conducted by those people having expert knowledge in the concerned subjects.

- Officials must ensure that they make a visit to the enterprises more frequently giving proper support system, clarifying doubts and proper guidance.

- Advanced level classes in topics like Organizational management, financial accounting, entrepreneurship and marketing have to be imparted at CDS level.

- $\quad$ Follow up classes at ADS level should be arranged for reinforcing the basic level courses given at NHG level.

- $\quad$ Proper guidance and communication must be given to the local authorities, semi government organizations and government aided institutions to purchase the products made by Kudumbashree units. They have to give priority to Kudumbashree units while inviting quotations from the suppliers. This ensures a ready marketability of the products.

- Kudumbashree should ensure that proper guidance should be given for the hygienic disposal of wastages for those who undertake waste disposal project.

- It would be better if Kudumbashree organizations select each panchayat and taluk and give awareness 
programmes, show documentary films on hygiene, cleanliness, importance of bio gas plant, water harvesting, solar energy, organic farming .

- The harmful and adverse effect of plastic pollution must be properly imparted to the public as well as to the entrepreneurs.

- Kudumbashree must compel and encourage the entrepreneurs to use eco friendly product in their enterprises.

- Women entrepreneurs should get the benefit of Information technology so that it can be utilized for passing timely and urgent information about processes, products and marketing strategies. This may help them sharpen their tactics to cope up with the competing world

- Permanent outlets must be sold only through proper advertisement.

- The appeal of the product can be enhanced by attractive packaging and designing of a logo for all Kudumbashree enterprises would give a professional touch and even a boost in their sales.

\section{CONCLUSION}

Kudumbashree became the lifeline to many of the poor women in the state of Kerala especially in the Malappuram. It is a massive anti poverty programme of the Government of Kerala aiming at eradicating poverty and salvage the destitute from the wretches of extreme deprivation. The relative success of Kudumbashree enterprises is a clear sign of widespread acceptance of community-based activities done to uplift the poor and downtrodden people. Poor Women have truly been empowered by joining in Kudumbashree organs like Neighbourhood groups and Micro enterprises. The State Poverty Eradication Mission-Kudumbashree- launched by the Government of Kerala State in India is a massive poverty eradication programme in contemporary history. It has been proved without any doubt that women empowerment is the best strategy for poverty eradication Women who were regarded as voiceless and powerless started identifying their inner power, their strength, opportunities for growth , and their role in reshaping their own destiny. The process of empowerment becomes the beacon light to their children, their families and to the society at large.

We can obviously say that the perceptions like capability, deprivation is one among the root causes of poverty and building capability of poor is inevitable to make poverty alleviation efforts sustainable is true in all sense. For attaining that goal, making the efforts to perfect Micro entrepreneurship is inevitable. Neighbourhood groups and their allied micro enterprises seems to be the one and only solution to save the rock bottom poor who live in utter distress and despair and who were left out from the coverage. Kudumbashree micro enterprises perceptibly depict how grass roots-level activities are essential for women's active participation in social and economic life. Even though there are so many pitfalls and shortcoming. These micro units has been successful in reaching the unreached through providing ways and means of living and financial independence. Even though the
Kudumbashree Micro enterprises are in their early stages, they show a clear symptom of sustainability. Around $75 \%$ of the units are running on profit. Shortcomings in some areas (in marketing and product standardization) still exist but through more exposure to training and experiences, these hurdles can be bypassed. Adopting all the ways of advertising, Appointing Professional agencies for outside advertising, Developing a separate logo and slogan for the product, Diversifying the product portfolio, Conducting regular exhibitions and Increasing small outlets and exclusive showrooms for Kudumbashree products are found to be some of the measures to build up a bright future for Kudumbashree enterprises. Anyway we hope that a bright and sunny tomorrow awaits them and this study may help them to reach out to that glittering day.

\section{REFERENCE}

[1] Subha rao K, Anirudda Banarjee, Jeamine Braith Waithe, Soniya Carvalho, Kene Ezamenari, Carol graham and Allan Thompson - Safety net programmes and poverty reduction lessons from cross country experience Washington DC World Bank, 1997

[2] Srivasthava RM(1999 ), Emerging profile of small women enterprises cum managers in India. A case study Women in Management Champions of Change,in Khair Jahan Sogra, University Press Ltd, Dhaka, Banladesh.Pp-69 .

[3] Manimekalai $M$ and Rajeswari G(July- Sept 2001), Nature and performance of informal self help groups, A case study from Tamil Nadu, Indian Journal of Agriculture-Economic Volume, 56, No 3,Pp 453-454 .

[4] Jose TK,-'winning together, A success story of Kudumbashree in kerala', Paper presented at Annual PRM at Tiruvanathapuram,2006

[5] K.Damodaran, (2006), 'A detailed Study on Role of Kudumbashree in Poverty Eradication In Kerala', Paper Presented at Department of Commerce, University of Calicut.

[6] Reshmi. R. 'Role of Kudumbashree Micro enterprises in alleviation of poverty with special reference to their marketing strategies'. Vol.1 Issue 12, Pp 174-177,186-187,(December 2012),ISSN 22773630

[7] S.P.Gupta, "Statistical Methods", Sultan Chand \& Sons Publication, New Delhi 110002,2002.

[8] C.R.Kothari, "Research Methodology", New age International (P)Ltd, Publishers,New Delhi.Pp95-98,100-102( 2009),ISBN : 978-81-2241522-3.

[9] The Kudumbashree Mission is functioning under the directorate of the Government of Kerala.

\section{WEBSITES}

[1] www.kudumbashree.org

[2] www.kerala.gov.in

[3] www.womenictenterprise.org 